\title{
Importance of reporting ancillary site characteristics, and management and disturbance information at ICOS stations
}

\author{
Matthew Saunders ${ }^{1 *}$, Sigrid Dengel ${ }^{2,3}$, Pasi Kolari ${ }^{3}$, Christine Moureaux $^{4}$, Leonardo Montagnani ${ }^{5,6}$, \\ Eric Ceschia ${ }^{7}$, Nuria Altimir ${ }^{8,3}$, Ana López-Ballesteros ${ }^{1}$, Sara Marañon-Jimenez ${ }^{9,10}$, Manuel Acosta ${ }^{11}$, \\ Katja Klumpp ${ }^{12}$, Bert Gielen ${ }^{13}$, Maarten Op de Beeck ${ }^{13}$, Lukas Hörtnagl ${ }^{14}$, Lutz Merbold ${ }^{14,15}$, Bruce Osborne ${ }^{16}$, \\ Thomas Grünwald ${ }^{17}$, Dominique Arrouays ${ }^{18}$, Hakima Boukir ${ }^{18}$, Nicolas Saby ${ }^{18}$, Giacomo Nicolini ${ }^{19,20}$, \\ Dario Papale ${ }^{19,20}$, and Michael Jones ${ }^{1}$
}

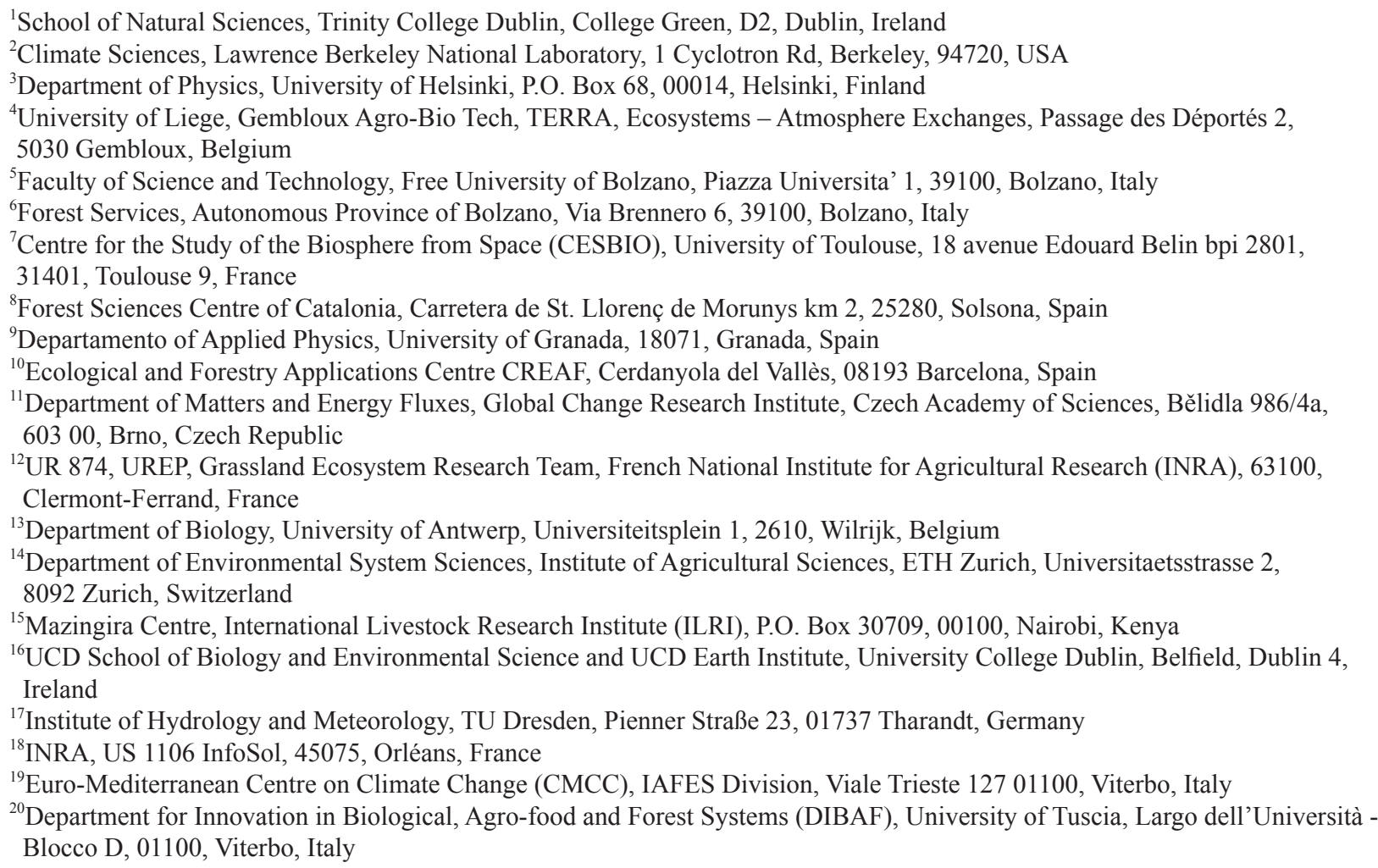

Received January 8, 2018; accepted August 22, 2018

Abstract. There are many factors that influence ecosystem scale carbon, nitrogen and greenhouse gas dynamics, including the inherent heterogeneity of soils and vegetation, anthropogenic management interventions, and biotic and abiotic disturbance events. It is important therefore, to document the characteristics of the soils and vegetation and to accurately report all management activities, and disturbance events to aid the interpretation of collected data, and to determine whether the ecosystem either amplifies or mitigates climate change. This paper outlines the

*Corresponding author e-mail: saundem@tcd.ie importance of assessing both the spatial and temporal variability of soils and vegetation and to report all management events, the import or export of $\mathrm{C}$ or $\mathrm{N}$ from the ecosystem, and the occurrence of biotic/abiotic disturbances at ecosystem stations of the Integrated Carbon Observation System, a pan-European research infrastructure.

Keyw ords: protocol, characterisation, management, disturbance, export

(C) 2018 Institute of Agrophysics, Polish Academy of Sciences 


\section{INTRODUCTION}

The key components and infrastructure that are required to assess carbon $(\mathrm{C})$, nitrogen $(\mathrm{N})$ and greenhouse gas (GHG) budgets at the ecosystem scale are well documented (Ciais et al., 2010; Neftel et al., 2006; Osborne et al., 2010; Schulze et al., 2010; Smith et al., 2010) and have been largely determined through experimental research networks. While the predominant $\mathrm{C}$ stocks and GHG fluxes such as the atmosphere-biosphere exchange of $\mathrm{C}$ and GHGs, soil organic C stocks (SOCs) or C losses through harvest events are generally well accounted for in many ecosystem scale studies, some emissions and $\mathrm{C} / \mathrm{N}$ losses associated with land management such as grassland renewal (Willems et al., 2011), biotic disturbance including damage from insects and pathogens (Hicke et al., 2012), and abiotic disturbance events associated with climatic extremes (Reichstein et al., 2013), are not. These are often neglected due to logistical, technical or financial constraints, or because they are perceived to represent a small proportion of the net ecosystem $\mathrm{C}, \mathrm{N}$ or water budgets. However, such losses often constitute fundamental drivers of the ecosystem $\mathrm{C}$ and $\mathrm{N}$ balance and are therefore required to provide a more comprehensive understanding of ecosystem scale biogeochemical cycles, warranting their inclusion in the experimental protocols undertaken at these long-term GHG observational stations (Lal, 2004; Osborne et al., 2010), including the Integrated Carbon Observation System (ICOS) a pan-European research infrastructure.

The key management and disturbance events that influence the $\mathrm{C}$ and $\mathrm{N}$ dynamics of terrestrial ecosystems include tillage (Davis et al., 2010; Eugster et al., 2010; Kutsch et al., 2010; Merbold et al., 2014; Willems et al., 2011), fertilisation (Fuß et al., 2011; Jassal et al., 2010; Snyder et al., 2009; Ventera et al., 2005), herbicide and fungicide applications (Lal, 2002), irrigation (Chamizo et al., 2017; Falloon and Betts, 2010; Verma et al., 2005) a change in the cropping system (Aubinet et al., 2009; Petersen et al., 2011) or biomass removal during grazing or harvest (Allard et al., 2007; Ceschia et al., 2010; Zanotelli et al., 2013); in addition to the effects of abiotic and biotic disturbance events which might be interrelated, such as extremes of temperature, hydrological changes and increased frequency of storm events (Ciais et al., 2005; Dahal et al., 2014; Hawkins et al., 2013; Hussain et al., 2011; Reichstein et al., 2013), pest infestations (Jimoh et al., 2013; Kurz et al., 2008; Straw et al., 2002), windthrow (Lindauer et al., 2014; Thürig et al., 2005; Ulanov, 2000), or fire (Amiro et al., 1999; Powers et al., 2013). These events may alter biogeochemical cycles within the ecosystem (e.g. windthrow or extremes of temperature) or may act both within and outside the ecosystem (e.g. grazing which will alter the plant canopy dynamics and will also result in the export of $\mathrm{C}$ and $\mathrm{N}$ from the ecosystem). Measuring the effects of these events on ecosystem scale GHG emissions will help to explain the overall spatial and temporal changes of the associated $\mathrm{C}$ and $\mathrm{N}$ losses. Additionally, it is also important to consider the effects of land management practices on $\mathrm{C}$ and $\mathrm{N}$ dynamics where, for example, plant biomass or soil is removed from the ecosystem due to grazing management, herbivory or the removal of harvested products in croplands, grasslands and forests, as this can represent a significant export of $\mathrm{C}$ and $\mathrm{N}$ from the ecosystem (SerranoOrtiz et al., 2011). Further consideration must be given to sites that are actively managed, as the $\mathrm{C}$ and $\mathrm{N}$ consumed by grazing animals is ultimately transformed into carbon dioxide $\left(\mathrm{CO}_{2}\right)$, methane $\left(\mathrm{CH}_{4}\right)$, excreta or animal biomass. Harvesting and grazing also modify the plant canopy which can have further implications for the canopy microclimate, soil chemistry, soil properties and soil microbial activity, nutrient distribution, water table and soil erosion by wind and water. All of these factors influence the Net Ecosystem Carbon Balance (NECB) and associated components of an ecosystem, and warrant adequate assessment in order to better understand both the short and long-term storage of $\mathrm{C}$ and $\mathrm{N}$.

Furthermore, many flux sites exhibit significant heterogeneity in the structure and composition of both soil and vegetation, which will determine the measurement techniques used, the interpretation of flux data and the extent and assessment of uncertainties in net ecosystem $\mathrm{C} / \mathrm{N}$ budgets (Göckede et al., 2004). It is therefore important to establish spatially representative assessments of these characteristics at each ICOS ecosystem station. The target area of interest at each station can be defined at its maximum, as the physical boundary, or delimitation of the land use class or ecosystem on which the flux measurements are undertaken. The site characterisation is required to determine the spatial variability in soil or vegetation characteristics across an ICOS ecosystem station to determine whether this variability influences the measured fluxes either by changing the seasonal or annual flux footprints or by altering plant canopy characteristics. An example of this is the occurrence of a disturbance event such as windthrow in forest ecosystems, which may influence the microclimatic conditions within, and the greenhouse gas dynamics of areas within the flux footprint (Knohl et al., 2002).

If the characterisation process is undertaken prior to the establishment of a new site, it will also aid in both the site selection process and the determination of the most suitable location for the flux tower, soil climate and ancillary vegetation measurement locations. When applied to an existing experimental site, the characterisation process may assist in the interpretation and analysis of primary flux data by aligning any modifications within the site to the flux footprint.

The objectives of this paper are to provide the guidelines required to describe and report the soil characteristics and vegetation composition at each ICOS ecosystem station, land management activities in addition to any abiotic or biotic disturbance events that may occur. The guidelines 
will ensure that any $\mathrm{C}$ and $\mathrm{N}$ losses or GHG emissions associated with relevant management interventions, abiotic or biotic disturbance events, imports or exports are identified and accounted for in a standardised manner at each flux station.

\section{METHODOLOGY}

\section{Site characterisation}

Description of ecosystem stations

Descriptive information on the site, defined as the target area of the eddy covariance (EC) system that is delimited by the boundaries of the land cover/site of interest, are provided using a standardised template. Within ICOS, all relevant variables and associated parameters are reported using the Biological, Ancillary, Disturbance and Metadata (BADM) templates which are described in detail in Papale et al. (2017). The basic information includes the ecosystem type, the ecosystem boundaries of the ICOS station and the representative area covered by the footprint of the EC system (determined using the ICOS recommended footprint model of Kljun et al., 2015) and vegetation composition, including species cover and distribution, geographic location and summary data for key climatic variables (e.g. mean annual temperature, precipitation, wind direction, radiation for each year of station operation). A description of the site history is provided for as long as records are available, including information on any previous land uses or land use change events, the occurrence of historical abiotic or biotic disturbance events, as well as current management practices. Management interventions need to be reported, including any soil or land management activities prior to planting (e.g. drainage or tillage), the sowing or planting date, species mixture, sowing rate or tree density, and any
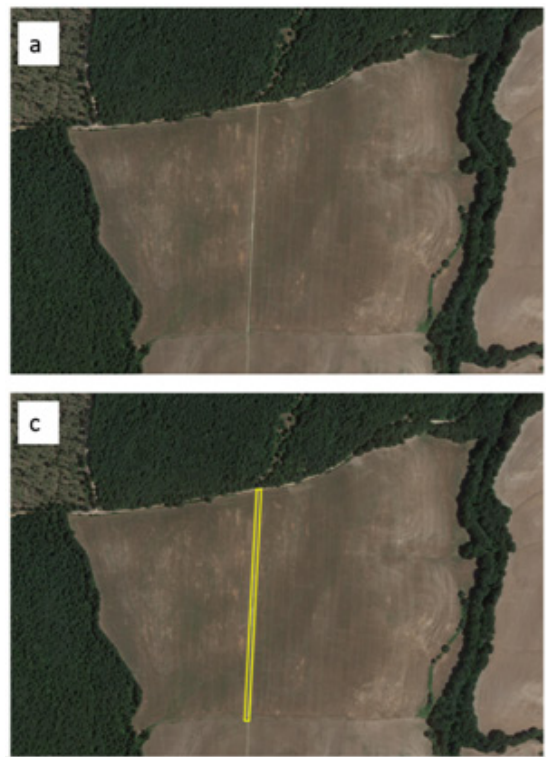

Fig. 1. Example of the determination of the target area for an ICOS station: $a$ - the ecosystem area of interest, $b$ - the identification of the target area delineated by the boundaries of the ecosystem, $\mathrm{c}$ - identification of area to exclude from the sampling design (e.g. roads), $\mathrm{d}$ - merging of polygons to identify the overall area for assessment. management interventions (e.g. thinning, pruning, grazing or harvesting) or amendments that have either taken place prior to the establishment of the measurement station or that take place on a regular basis (e.g. liming, fertilization, pesticides, irrigation).

\section{Soil and vegetation sampling and assessment}

The soil characteristics, vegetation composition, cover, distribution and biomass across the site need to be assessed when setting up a new station. Existing stations that have collected information previously will report how this information has been determined to the Ecosystem Thematic Centre (ETC), the ICOS central facility coordinating the ecosystem network, so that the methodology used to collect this data can be reviewed with regard to the requirements and recommendations of ICOS characterisation protocols (Gielen et al., 2017a; Op de Beeck et al., 2017a,b; for characterisation protocols for forests, grasslands and mires respectively). Using this approach, the station Principle Investigator (PI) will initially map the boundaries of the ecosystem and will identify areas where the allocation of sampling points is not possible, such as roads or other infrastructure for example (Fig. 1). This information will be submitted to the ETC which then partitions the target area into ten geographically compact, randomly generated subareas of equal proportion (Brus et al., 1999 and Walvoort et $a l ., 2010$ for further details on this sampling methodology) (Fig. 2a). The ETC will also provide coordinates to assign two first order sparse measurement plots (SP-I-order) to each of the ten sub-areas (to identify 20 SP-I-order plots in total across the target area of interest) using a stratified random scheme, which is scale-independent (Fig. 2b). In addition, twenty second order (SP-II-order) sampling locations are assigned randomly within a $10 \mathrm{~m}$ circumference
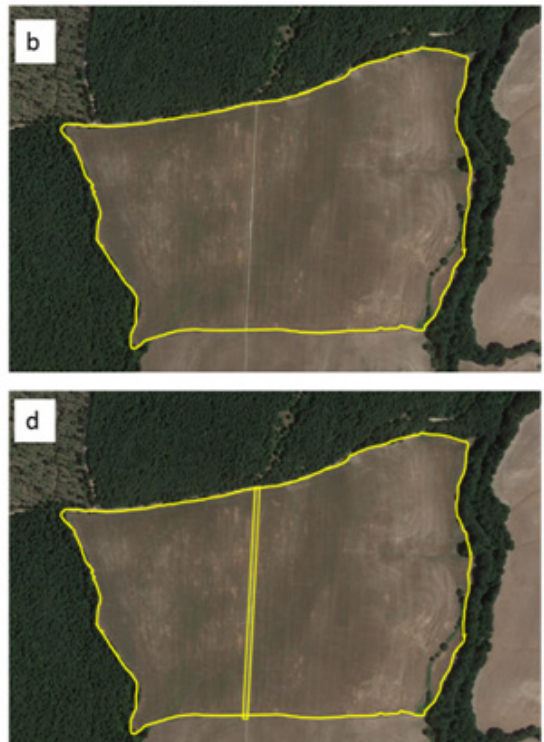

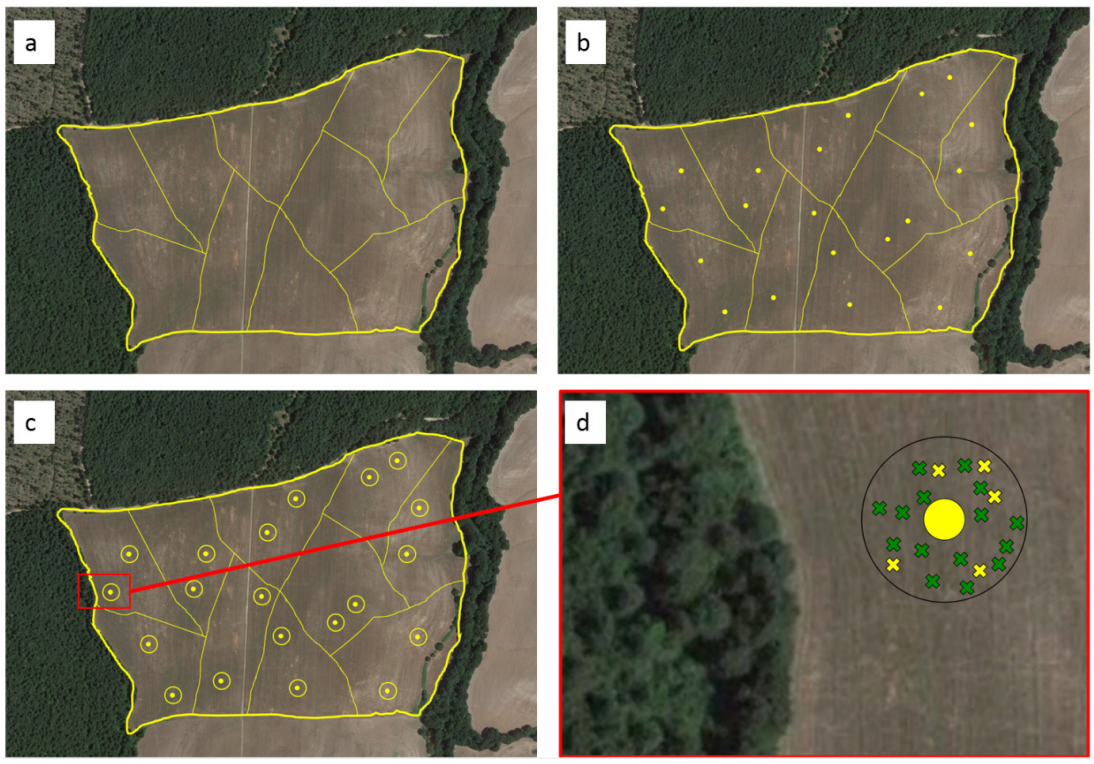

Fig. 2. Illustrative example showing the ecosystem of interest and the location of both SP-I-order and SP-II-order sampling locations: $\mathrm{a}$ - the target area is sub-divided into ten equal compartments, $\mathrm{b}$ - the random location of two SP-I-order sampling points in each cell, $\mathrm{c}$ - the area around each SP-I-order point where the additional 20 SP-II-order points will be randomly allocated, $d$ - an example of one SP-1-order point showing the location of the additional SP-II-order points used for the site characterisation process (yellow) and the location of the SP-II-order-R points for subsequent assessment (green).

of each SP-I-order sampling point (Fig. 2c and d). Five randomly selected SP-II-order points are used for the characterisation of vegetation at each ecosystem station, while the remaining SP-II-order points are held in reserve (SP-IIorder-R) and are re-sampled after a 10 year period, or when a disturbance event has occurred (Fig. 2d). The SP-I-order points need to be separated by a distance of $30 \mathrm{~m}$ from the next adjacent SP-I-order point and $10 \mathrm{~m}$ from the boundary of the target area of interest. If such spatial separation does not occur during the randomised allocation of sampling points or if a SP falls on an exclusion area, an additional SP-I-order point is randomly assigned using the approach described above. In addition to the SPs, two to five continuous measurement plots $(\mathrm{CP})$ are also assigned to the station in forest and cropland systems, which are used for continuous measurements of soil-meteorological variables and repeated measurements of ancillary vegetation traits. Continuous measurement plots are not assigned to grassland stations, while the number of CPs assigned to mire ecosystems is variable and depends on the number of plant communities and associated ecotypes identified as part of the vegetation characterisation process. An example of the distribution of both SPs and CPs at an ICOS station is illustrated in Fig. 3. If a SP plot falls within a CP location and the station PI considers that any such overlap could negatively impact on the measurements made, there are two possible options. Firstly, the CP locations are defined once the location of the SPs have been determined and provided to the PI by the ETC, secondly, the area covered by the planned $\mathrm{CP}$ are considered as exclusion areas and are not used in the characterisation sampling design, however this request must be submitted directly to the ETC. Once the station PI has been provided with the coordinates for each of the SP sampling points, these form the centre of the SP plots used for vegetation and soil characterisation and need to be located with an accuracy of $\leq 2 \mathrm{~m}$ and $\leq 1 \mathrm{~m}$ in forest and sparse-vegetation ecosystems, respectively. The exact corresponding coordinates are then recorded, detailing up to the fifth digit of degree decimal format of the geographic coordinates using the WGS84 geodesic datum, with a GPS or other topographical tool and with a precision of $1 \mathrm{~m}$ in forests and $0.5 \mathrm{~m}$ in low-stature canopies. These points

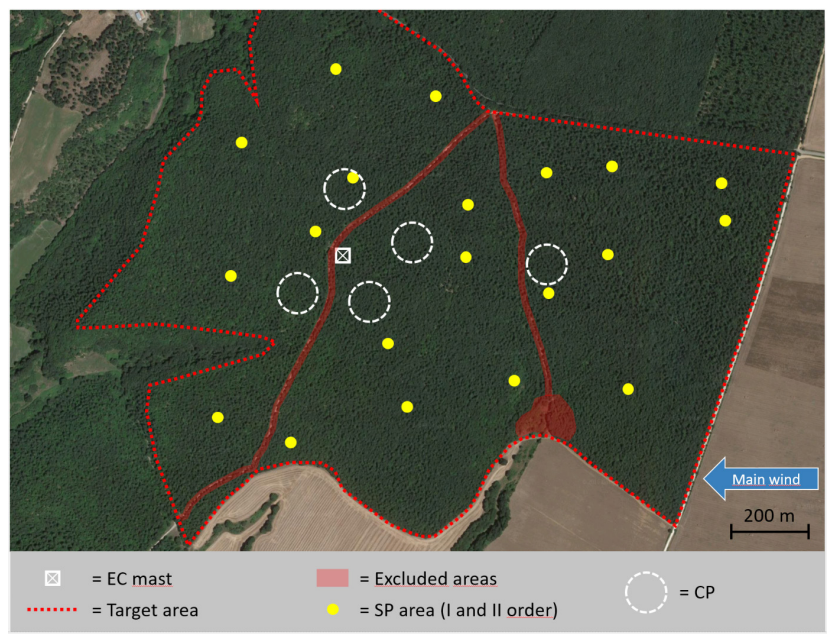

Fig 3. An example of the overall sampling scheme for ICOS stations, showing the location of both SP-I-order and CP plots in addition to areas that have been excluded as part of the characterisation sampling regime. 


\section{Station team $\quad$ ETC}

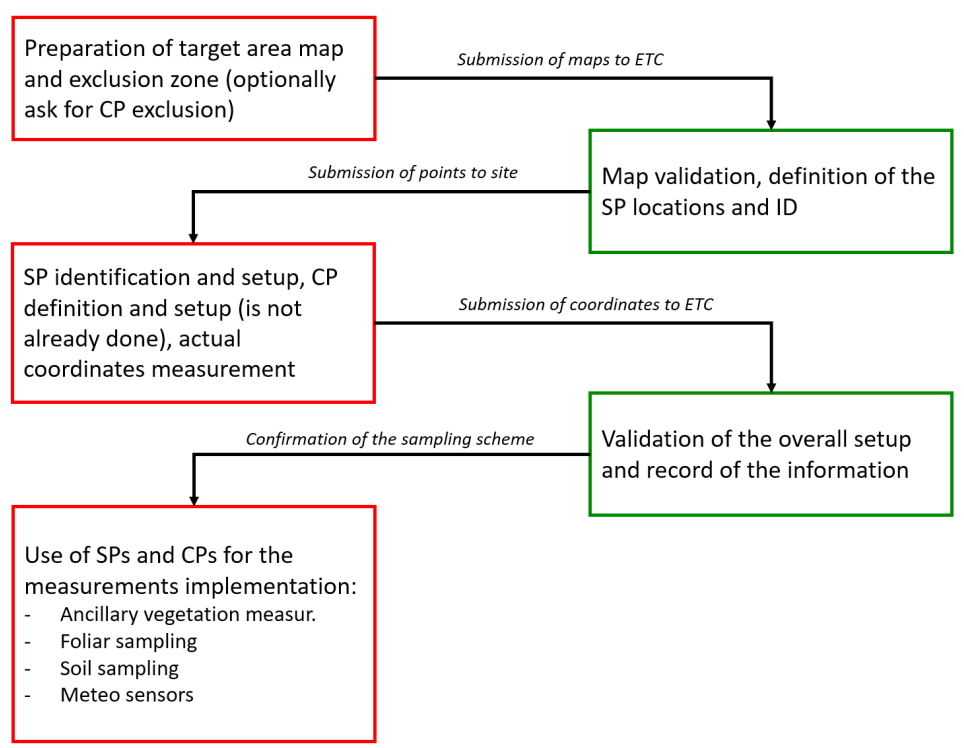

Fig. 4. Summary of the workflow for the development of a spatial sampling scheme at ICOS ecosystem stations for site characterisation and repeated measurement campaigns.

need to be permanently marked to facilitate the subsequent identification of sampling points when required. The coordinates of the SP-I-order points located at each station must be reported to the ICOS ETC at the time of the site characterisation exercise, while the SP-II-order points only need to be reported when they are sampled. The submission of information is undertaken using the BADM data template (Papale et al., 2017). This information is then validated by the ETC and the spatial sampling scheme for site characterisation and subsequent repeated measurement campaigns is complete. The workflow associated with this process is summarised in Fig. 4. The plot type and related measurements are summarised in Table 1 for specific measurement methodologies. The main objective of the vegetation assessment is to characterise the plant community structure, composition and relative health, and if repeated, to allow the detection of any long-term changes and to identify the mechanisms of change. This will require a census survey of plant species abundance in each of the SPs, based on the relative frequency of each species. The Plant List Database (http://www.theplantlist.org) is used as the reference nomenclature for plant species classification, further details can be found in Pellis and Papale (2017). Further information can be found in the ICOS Ecosystem Instructions for Plant Species Reporting. The visual assessment procedure, if also complemented with hemispherical photographs or phenocam images, is also important for the identification of the occurrence of biotic or abiotic disturbance events, such as the presence of pests or diseased material within the plant canopy as well as recording changes to the canopy structure due to harvest (e.g. thinning of forest canopies) or the influence of wind (e.g. windthrow or flattened crops). If management operations such as forest thinning are planned either before or during the site characterisation process or in the initial measurement year, it is recommended to sample the vegetation in the year prior to the operations in addition to the year after disturbance (if known). The characterisation of vegetation at grassland, forest and mire ecosystem stations is described below, for cropland systems it is required to report the primary crop species only. All information is reported using the BADM template (Papale et al., 2017).

Grassland ecosystems:

The assessment of species composition is carried out at each of the five SP-II-order plots located around each of the 20 SP-I-order plots within the target area (100 sampling locations in total), during the first year of ICOS measurements. It is best practice to undertake this assessment close to the peak biomass, and the timing of flowering should be considered to aid identification as the plants present must be identified at the species level. If identification at species level proves to be very difficult identification at genus level may be sufficient, but this must be reported to the ETC. Measurements of aboveground biomass (AGB) for characterisation purposes are made at two of the SP-II-order plots located around each of the 20 SP-I-order plots within the target area. This measurement also needs to be conducted when the standing biomass is at its peak and is undertaken using destructive sampling techniques. Above ground biomass is separated between green and non-green plant material and the green fraction of each of the plant functional groups present is also separated. Further instructions 
Table 1. The presence of SPs and CPs in different ecosystem types and the required measurements that are made at each of the plots. Table derived from the ICOS spatial sampling instructions

\begin{tabular}{|c|c|c|}
\hline Ecosystem & Sparse measurement plots (SP) & Continuous measurement plots $(\mathrm{CP})$ \\
\hline Forest & $\begin{array}{l}\text { Vegetation species } \\
\text { green area index } \\
\text { Diameter at breast height } \\
\text { Tree height } \\
\text { Soil characteristics }\end{array}$ & $\begin{array}{l}\text { Repeated ancillary vegetation measurements } \\
\text { (green area index, aboveground biomass, litter, } \\
\text { foliar sampling for chemical analysis) } \\
\text { Continuous soil-meteorological variables }\end{array}$ \\
\hline Cropland & $\begin{array}{l}\text { Biomass and crop yield at harvest } \\
\text { Soil characteristics }\end{array}$ & $\begin{array}{l}\text { Repeated ancillary vegetation measurements (green area } \\
\text { index, aboveground biomass, litter, foliar analysis) } \\
\text { Continuous soil-meteorological variables }\end{array}$ \\
\hline Grassland & $\begin{array}{l}\text { Vegetation species } \\
\text { Repeated ancillary vegetation measurements } \\
\text { (green area index, aboveground biomass, litter foliar } \\
\text { sampling for chemical analysis) } \\
\text { Soil characteristics }\end{array}$ & Not present ${ }^{1}$ \\
\hline Mire & Vegetation species $^{2}$ & $\begin{array}{l}\text { Repeated ancillary vegetation measurements (green area } \\
\text { index, aboveground biomass, foliar sampling for } \\
\text { chemical analysis) } \\
\text { Continuous soil-meteorological variables }\end{array}$ \\
\hline
\end{tabular}

${ }^{1}$ Grassland ecosystems do not need to use CPs. ${ }^{2}$ Mire ecosystems do not always need to use SPs where access to the entire target area of interest might be difficult. This is reviewed by the ETC on a case-specific basis.

can be found in the ICOS Ecosystem Instructions for site characterisation measurements in grasslands (Op de Beeck et al., 2017a).

Forest ecosystems:

At each SP-I-order location a $15 \mathrm{~m}$ radius circular plot is defined with the centre coinciding exactly with the SP-Iorder point. In forest plantations, where the trees are spaced at regular intervals, the area to be considered around each SP-I-order location is not a circular plot but must instead be a square plot of $700 \mathrm{~m}^{2}$, centered on the SP-I-order location. The corners will be located between the rows of trees and thus the square shape may be adapted to a rectangle if needed. A minimum of four rows of trees must be included. For each tree with a diameter at breast height (DBH) $>5 \mathrm{~cm}$ growing inside the circular or rectangular plot, its species and health status are noted, and the DBH and height is measured following the methodology described in the Instructions for Ancillary Vegetation Measurements in Forests (Gielen at al., 2017b). The AGB of the forest overstorey is determined using allometric relations based on DBH and tree height. The understorey aboveground biomass is not included in the site characterisation, however in forest systems where extensive understory vegetation is present this should be reported by the station PI to the ETC using the BADM template (Papale et al., 2017). All measured trees are either marked or precisely mapped to ensure that the same trees will be considered in the next measurement campaign. The green area index (GAI) of the overstorey is determined by means of digital hemispherical photography if the seasonal maximum GAI is $<6 \mathrm{~m}^{2}$ $\mathrm{m}^{-2}$, and by linear ceptometry if the seasonal maximum
GAI is $>6 \mathrm{~m}^{2} \mathrm{~m}^{-2}$. Full instructions can be found in the ICOS Ecosystem Instructions for Site Characterisation Measurements in Forests (Gielen et al., 2017a).

Mire ecosystems:

If the target area is accessible, the vegetation survey is carried out at each of the five SP-II-order plots located around each of the twenty SP-I-order plots within the target area (100 sampling locations in total), during the middle of the first growing season of the ICOS station operation. If access to the target area is difficult and only accessed, for instance, using boardwalks, the site characterisation has to be undertaken based on a vegetation survey at a number of locations along the installed boardwalks. The plant community types of the vegetation samples are statistically categorised using two way indicator species analysis (TWINSPAN clustering algorithm) (Chahouki, 2012). With this information, a distribution map of the plant community types can be generated. This map is then used to derive the fraction of the target area that each of the community types occupies. The vegetation survey must be performed at a total number of 100 sampling locations along both sides of the installed boardwalks. The position and total length of the boardwalks must be communicated to the ETC. The distance between the centers of adjacent sampling locations should ensure that the 100 sampling locations are equally spaced along the boardwalk network and alternated on both sides of the entire boardwalks. The center of each sampling location must be $50 \mathrm{~cm}$ away from the boardwalk edge. The plants present must be identified at the species level. If identification at species level proves to be challenging, identification at genus level may be sufficient or may be based on the main strata or the microtopographical features 
that support the distinct community types (e.g. hummock/ strings, lawn, hollow/flarks). The percentage species cover should be estimated and recorded, and if a sampling location falls on a pool system it can be classified as such. Full instructions can be found in the ICOS Ecosystem Instructions for Site Characterisation Measurements in Mires (Op de Beeck et al., 2017b).

The initial soil description at the ecosystem stations will be undertaken by taking a soil core (for non-stony/coherent soils) or digging a soil pit (for stony/incoherent soils) at each SP-I-order point. If access to each of the SP-I-order plots is difficult, the total number of SP-I-order points sampled can be reduced but communicated to the ETC. Following this five SP-II-order plots located around each of the 20 SP-I-order plots are sampled by taking soil cores to a depth of $100 \mathrm{~cm}$ in non-stony/coherent soils. For soils where coring is problematic, soil pits can be dug to a depth of $100 \mathrm{~cm}$ at three SP-II-order plots located around each of the 20 SP-I-order plots.

\section{The export of $\mathrm{C}$ and $\mathrm{N}$ in vegetation and soils}

The export of $\mathrm{C}$ and $\mathrm{N}$ out of the target area of interest at ICOS stations occurs when $\mathrm{C}$ or $\mathrm{N}$ that is non-gaseous or dissolved, or contained within plant biomass or soil, is removed or lost from the site. In certain ecosystems, such as grasslands, additional consideration must be given to the transformation of $\mathrm{C}$ and $\mathrm{N}$ by grazing animals, where material consumed can either be emitted as $\mathrm{CO}_{2}$ or $\mathrm{CH}_{4}$, returned to the soil in excreta, or transformed into animal biomass and exported as livestock that leave the ecosystem. The main components of the export of biomass and $\mathrm{C}$ and $\mathrm{N}$ that need to be reported to the ETC are the harvest products from production systems (e.g. grain, silage, fruits, timber, grazing), which are recorded using the BADM template (Papale et al., 2017). Similarly, the management or removal of harvest residues must also be reported.

The station PI can then independently investigate these exports further by assessing soil $\mathrm{C}$ and $\mathrm{N}$ that adheres to and is removed with the below ground component of some crops, as well as through wind or water erosion (in both particulate or dissolved form). Other aspects including the conversion of grassland biomass to animal biomass can be assessed according to reporting guidelines (IPCC, 2003), and by recording the live weight and stocking density of animals that graze the target area of interest. It is important, however, to ensure that losses through grazing are not double-counted. As for losses via enteric fermentation, these fluxes may either be measured at the ecosystem scale (EC-techniques) or at the individual/animal scale using the sulphur hexafluoride tracer technique (PinaresPatino et al., 2007). While these latter techniques provide greater detail on $\mathrm{C}$ exports, only the biometric assessment of harvest removals are required to be reported to the ETC.

\section{The import of $\mathrm{C}$ and $\mathrm{N}$ through site amendments}

Site amendments refer to any material that is added to or incorporated into the soil to enhance ecosystem productivity. These amendments are applied to improve soil physical and chemical properties such as nutrient status, water retention, permeability, infiltration, aeration or structure. Soil amendments vary in origin and composition and may consist of either organic or inorganic constituents. Typical soil amendments include mineral and/or organic fertilisers, soil conditioners (e.g. compost or organic residues), cover crops as a green manure, liming, pesticides and irrigation. It is important to report the $\mathrm{C}$ and $\mathrm{N}$ content of amendments, the timing and rates of application (Table 2), the application methodology, any spatial variability in application and the occurrence of any conditions that require repeated or amended applications according to requirements (e.g. pest/pathogen outbreak or limited water availability). Additionally, including an estimation of the fossil fuel consumption derived from these management practices will be of benefit in terms of the accuracy of NECB estimates, particularly for intensively managed ecosystems.

\section{Biotic and abiotic disturbance events}

Biotic interactions can have both positive (symbiotic associations such as mycorrhizal or rhizobial associations) and negative impacts (pests) on the primary productivity of plant species. Depending on the intensity of the biotic interaction some organisms can have a negative impact on plant growth and are the focus in this instance. They include insects (which can be categorised by both feeding habit, chewing, sucking, rasping, and the parts of the plant eaten; roots and rhizomes or stems and foliage), pathogens (fungi, bacteria, viruses and mycoplasmas), nematodes and other animals (birds, deer, rabbits and rodents). They can influence different components of the $\mathrm{C}$ and $\mathrm{N}$ cycles (gross primary production, ecosystem respiration, net primary production and net ecosystem production) and may impact different plant organs at different physical locations within the plant system (roots, trunk, branches or foliage) or within the soil. Given the complexity of interactions between the main plant type(s), the associated organism responsible for the interaction, across different ecosystem compartments and time scales, the quantification of their activity is

Table 2. The common units for various site amendments

\begin{tabular}{ll}
\hline Amendment & Units \\
\hline Fertiliser inorganic & $\mathrm{kg} \mathrm{N} \mathrm{m}^{-2}, \mathrm{~kg} \mathrm{P} \mathrm{m}^{-2}, \mathrm{~kg} \mathrm{~K} \mathrm{~m}^{-2}$ \\
& $\mathrm{~m}^{3} \mathrm{~m}^{-2}$ (liquid manure) \\
Fertiliser organic & $\mathrm{kg} \mathrm{m}^{-2}$ (solid manure) \\
& $\mathrm{kg} \mathrm{C} \mathrm{m}^{-2}, \mathrm{~kg} \mathrm{~N} \mathrm{~m}^{-2^{*}}$ \\
Pesticide/herbicide & $\mathrm{mg} \mathrm{or} \mathrm{ml} \mathrm{(active} \mathrm{matter)} \mathrm{m}^{-2}$ \\
Irrigation & $\mathrm{m}^{3} \mathrm{~m}^{-2}$ \\
& $\mathrm{~m}^{-2}$ \\
\hline
\end{tabular}

${ }^{*} \mathrm{C} / \mathrm{N}$ content of liquid or solid fertiliser. 
not straightforward. It is also prudent to consider the interactions between biotic and abiotic disturbance events, as the prevalence of a biotic pest may enhance the vulnerability of the ecosystem to other pests and pathogens or to adverse environmental conditions and vice versa.

Abiotic disturbance events are caused by non-living factors and when these events surpass their common range of variability, in terms of their frequency, return interval, intensity, duration and timing, they are considered extreme. Moore and Allard (2010) categorised these events under five key headings: meteorological (cyclones, storms [wind, snow, ice/hail, dust/sand]), climatological (drought, heat stress), hydrological (floods), geophysical (tsunamis, earthquakes and volcanic eruptions) and anthropogenic (fires, oil spills, air pollution and radioactive contamination). Many of these events however, do not occur in isolation and are closely linked. The occurrence, size, intensity, severity, spatial distribution, frequency, return interval and rotation period all need to be considered in the detection and description of such events. The occurrence of disturbance events will be identifiable from the ICOS station meteorological data when compared to the long-term 30 year mean climatological data. The period over which this long-term mean is determined as well as supplementary information including the location of the station from which this data is derived, the measurement variables and data acquisition, management and quality control need to be reported to the ETC. This information can be used for example to identify storm events (based on maximum wind speed and precipitation regimes), drought events, and temperature extremes (heat waves, frost). Site-specific thresholds, for such conditions, need to be defined against long-term (30 year), regional scale meteorological records in order to detect a potential disturbance event that can then be reported within the meta-data. The meteorological data can also be used to identify periods where there is an increase in the potential probability of an abiotic disturbance event (the possibility of flooding or fire). Where such possibilities exist, changes in site conditions can be assessed using both remote means (webcams), but also by regular manual/visual site assessments. The detection of these events requires the ICOS station PI to consult other key ICOS measurement protocols (EC data acquisition/processing, chamber methodologies and ancillary vegetation measurements, to ensure that they adequately capture the impact of any disturbance on $\mathrm{C}, \mathrm{N}$ losses as well as GHG emissions.

The methodological techniques that can be utilised to assess the impacts of biotic and abiotic disturbances on the aboveground biomass component of terrestrial ecosystems include the use of hemispherical imagery, inclined phenocams (Wingate et al., 2015), ceptometer measurements of light interception and an assessment of foliar characteristics.

\section{RESULTS AND DISCUSSION}

A good understanding of the $\mathrm{C}, \mathrm{N}$ and GHG dynamics of terrestrial ecosystems is needed to determine, under current climatic conditions and management interventions, whether they amplify or mitigate climate change (Lin et al., 2017; Prescher et al., 2010). Through the development and coordination of a global network of experimental and observation platforms (e.g. Fluxnet), the scientific community has been able to capture, with varying spatial and temporal success, the impacts of management, climatic variability (including inter-annual variability and climatic extremes) and biotic interactions on net ecosystem C, N and GHG budgets (Baldocchi et al., 2001; Dolman et al., 2008). By maintaining these networks and by standardising the experimental approaches used, which is a key objective of the ICOS network, there is the potential capability to capture how short-term climatological or anthropogenic changes influence $\mathrm{C}$ and $\mathrm{N}$ dynamics at the site-scale (Richardson et al., 2007). The information provided by these networks also provides an assessment of the adaptive capacity or resilience of terrestrial ecosystems to environmental change (Holling, 1973), and how this information translates across larger spatial and temporal scales (Beer et al., 2012; Ciais et al., 2005; Montagnani et al., 2017).

Characterisation of the soils and vegetation of eddy covariance sites, particularly within the target area of interest, is required for a comprehensive assessment of the drivers underpinning any measured fluxes. This is particularly important in ecosystems where natural spatial variability influences net ecosystem C, N and GHG exchange, such as in the arctic tundra (Pirk et al., 2017) or in forest ecosystems for example (de Araujo et al., 2010). However, even in relatively homogenous canopies, such as croplands, intensively managed grasslands and mono-culture forest plantations, spatial variability is often an important factor. Ecosystem scale $\mathrm{C}$ and $\mathrm{N}$ dynamics will, in addition, always be influenced by nutrient limitation, pests and diseases or wind damage (Hou et al., 2016; Niu et al., 2010; Sjögersten et al., 2011; Thürig et al., 2005). Therefore, regular assessments of canopy structure are necessary when investigating the drivers of atmosphere-biosphere GHG exchange. Furthermore, it is also important to consider how heterogeneity in the wider landscape might influence the turbulent exchange of trace gases at the site-scale (Stoy et al., 2013). Characterisation of the heterogeneity of soil properties across the target area of interest is also crucial, as key physical and chemical soil properties, such as bulk density, mineralogy, porosity or $\mathrm{pH}$, for example, can influence a range of parameters (e.g. water availability, cation exchange capacity, nutrient availability, $\mathrm{C}, \mathrm{N}$ and organic matter) that directly influence plant productivity and soil microbial activity, and thus impact on gross primary productivity (GPP) and ecosystem respiration $\left(\mathrm{R}_{\text {eco }}\right)$. Such variability in physical characteristics could also have an 
impact on soil-meteorological variables, or rates of soilderived trace gas emissions (Stoyan et al., 2000) and therefore need to be quantified.

The influence of land use, vegetation type and management interventions can have a significant impact on the $\mathrm{C}$, $\mathrm{N}$ and GHG dynamics of terrestrial ecosystems (Ceschia et al., 2010; Lal, 2004). For example, the prevalence of weed species have been shown to significantly increase the net $\mathrm{C}$ sink strength of irrigated olive orchards (Chamizo et al., 2017), while soil disturbance through tillage is widely considered to result in a decrease in SOCs (Baker et al., 2007). Increases in rates of soil $\mathrm{CO}_{2}$ efflux have been observed in different cropping systems during tillage events (Reicosky et al., 1997), while the ploughing of grassland ecosystems has been shown to result in a short-term increase in soil $\mathrm{CO}_{2}$ efflux (Willems et al., 2011). The application of soil amendments to enhance plant productivity in agricultural systems can have both a positive and negative atmospheric feedback. The addition of organic matter to grazed grasslands ecosystems has been shown to increase rates of soil respiration but have little or no impact on $\mathrm{CH}_{4}$ and nitrous oxide $\left(\mathrm{N}_{2} \mathrm{O}\right)$ emissions, while enhancing net ecosystem productivity (Ryals and Silver, 2013). However, the application of inorganic nitrogen-based fertilisers is widely known to increase the rate of $\mathrm{N}_{2} \mathrm{O}$ emissions from agricultural soils (Abdalla et al., 2010; Hyde et al., 2006). The magnitude of these $\mathrm{N}_{2} \mathrm{O}$ emissions depends on substrate supply, the rate and form of $\mathrm{N}$ application, soil water content, $\mathrm{pH}$ and temperature (Baggs, 2010; Hörtnagl and Wohlfahrt, 2014; Skiba et al., 1999). Soil-derived $\mathrm{N}_{2} \mathrm{O}$ emissions show significant spatial and temporal variability, being characterised by both emissions at 'hot-spots' or during 'hot-moments' (Butterbach-Bahl et al., 2013). This highlights the importance of characterising the soils and vegetation and reporting the management practices at ICOS ecosystem stations, in order to enhance the spatial interpretation of GHG flux data from both chamber-based measurements and the eddy covariance footprint. Moreover, it is important to report the timing and magnitude of any agricultural amendments such as pesticides and herbicides to adequately assess any impacts on the measured GHG fluxes.

Abiotic disturbance and biotic interactions caused by climatic extremes such as droughts, temperature anomalies and precipitation events or by insect or pathogen infestation can have a significant impact on plant and soil microbial physiological functions and therefore on $\mathrm{C}$ and $\mathrm{N}$ dynamics of terrestrial ecosystems (Frank et al., 2015; Hicke et al., 2012). The impacts of such events are manifested in both short-term and long-term alterations in the net ecosystem productivity of terrestrial ecosystems. For example, extreme precipitation events during the growing season had a negative effect on annual forest GPP, whilst exceptional/extreme low-temperature events during winter had negligible long-term effects but were associated with significant short term reductions in GPP (Saunders et al.,
2014). Stand-replacing disturbance events (e.g. fire and insect infestation) have been shown to result in long-term C losses (10-20 years) from forest ecosystems in North America (Amiro et al., 2010), while soil $\mathrm{CO}_{2}$ emissions and post-fire forest management have been shown to influence the recovery of the ecosystem $\mathrm{C}$ sink (Marañon-Jiménez et al., 2011; Serrano-Ortiz et al., 2011). Furthermore, the utility of long-term observational and experimental platforms across Europe has been highlighted in the detection of a pan-European reduction in primary productivity following extreme periods of heat and drought (Ciais et al., 2005). Again, this underlines the need for the regular assessment and characterisation of the vegetation at ICOS flux stations in order to detect both small and large-scale disturbance events, and to align this with the ancillary vegetation and meteorological protocols utilised within the network.

Theoretically, losses of $\mathrm{C}$ and $\mathrm{N}$ from an ecosystem occur when the $\mathrm{C}$ and $\mathrm{N}$ in plant or animal biomass, soil or water is removed across the boundary of the ecosystem of interest. At ICOS stations the removal of biomass in harvested products needs to be reported, however it is perhaps worthwhile to also highlight here there are other exports of $\mathrm{C}$ and $\mathrm{N}$ that may have a significant impact on net ecosystem $\mathrm{C}$ and $\mathrm{N}$ budgets. For example, losses of biogenic $\mathrm{C}$ through leaching at grassland and cropland stations across Europe equated to approximately $22 \%$ and $25 \%$ of the measured net ecosystem exchange (NEE) at these sites (Kindler et al., 2011). Losses of dissolved carbon and/or nitrogen from forest systems have been shown to exhibit greater variability, with negligible losses at some sites possibly due to soil related factors and the high productivity of these ecosystems (Kindler et al., 2011), while other unproductive sites have reported losses up to $10 \%$ of NEE (Gielen et al., 2011). Furthermore, it has been estimated that up to $30 \mathrm{Mg} \mathrm{ha}^{-1}$ of soil can be removed from agricultural soil during the harvest of crops such as sugar beet, which can have significant implications for soil-based C stocks (Osborne et al., 2010; Ruysschaert et al., 2005). The information generated from ICOS stations that assess $\mathrm{C}$ and $\mathrm{N}$ exports in more detail, will provide further evidence of the key factors that influence such losses and their relevance for different ecosystems.

\section{CONCLUSIONS}

1. The standardisation of methodologies to characterise Integrated Carbon Observation System ecosystem stations and the reporting of the impacts of management and disturbance on $\mathrm{C}, \mathrm{N}$ and greenhouse gas emissions are essential for developing a coherent pan-European flux network.

2. The characterisation of soils and vegetation at the integrated carbon observation system research stations will allow a better account of the site-specific spatial variability of these ecosystem components and the impact they may 
have on net ecosystem $\mathrm{C}, \mathrm{N}$ and greenhouse gas dynamics. This will also assist in the appropriate allocation of new EC stations.

3. Initial measurements at the SP-I-order and SP-IIorder points and the long-term assessment of SP-II sampling locations in integrated carbon observation system ecosystem stations will provide information for the identification and quantification of the impact of disturbance events on C, $\mathrm{N}$ and greenhouse gas dynamics.

4. A close collaboration between the station PI and ETC is essential for reporting any management related events or site-related amendments that may be relevant for the interpretation of flux data.

5. To ensure the robust calculation of net ecosystem $\mathrm{C}$ and $\mathrm{N}$ stocks it is required to report any $\mathrm{C}$ and $\mathrm{N}$ losses that occur with harvest events. It is also important to assess other potential $\mathrm{C} / \mathrm{N}$ imports or exports, such as site amendments or leached biogenic $\mathrm{C}$ that might represent a substantial gain/loss of $\mathrm{C}$ and or $\mathrm{N}$ from the ecosystem, although the latter is not mandatory within the integrated carbon observation system measurement guidelines.

\section{ACKNOWLEDGEMENTS}

Matthew Saunders would like to acknowledge the Irish Environmental Protection Agency in the provision of travel support to attend ICOS meetings. Lutz Merbold and Lukas Hörtnagl acknowledge funds received under the Swiss National Science Foundation funded project ICOSCH (grant agreements: 20FI21_148992, July 2013 to June 2017; 20F121_173691, since July 2017) and of ETH Zurich (0-23184-15, June 2015 to December 2017) The authors acknowledge all active members of the ICOS ecosystem working groups and all other people who contributed to the development of the ICOS ecosystem domain and measurement protocols. The authors would also like to recognise the anonymous reviewers for their valuable remarks, constructive comments and corrections that helped to increase the overall quality of the manuscript.

Conflict of interest: The Authors declare no conflict of interest.

\section{REFERENCES}

Abdalla M., Jones M., Ambus P., and Williams M., 2010. Emissions of nitrous oxide from Irish arable soils: effects of tillage and reduced $\mathrm{N}$ input. Nutrient Cycling in Agroecosys., 86, 53-65.

Allard V., Soussana J.F., Falcimagne R., Berbigier P., Bonnefond J.M., Ceschia E., D'hour P., Henault C., Laville P., Martin C., and Pinares-Patino C., 2007. The role of grazing management for the net biome productivity and greenhouse gas budget $\left(\mathrm{CO}_{2}, \mathrm{~N}_{2} \mathrm{O}\right.$ and $\left.\mathrm{CH}_{4}\right)$ of seminatural grassland. Agric. Ecosys. Environ., 121, 47-58.

Amiro B.D., Barr A.G., Barr J.G., Black T.A., Bracho R., Brown M., Chen J., Clark K.L., Davis K.J Desai A.R., Dore S., Engel V., Fuentes J.D., Goldstein A.H., Gulden M.L., Kolb T.E., Lavigne M.B., Law B.E., Margolis H.A., Martin T., McCaughey J.H., Misson L., Montes-
Helu M., Noormets A., Randerson J.T., Starr G., and Xiao J., 2010. Ecosystem carbon dioxide fluxes after disturbance in forests of North America. J. Geophysical Res., $1-13$.

Amiro B.D., MacPherson J.I., and Desjardins R.L., 1999. BOREAS flight measurements of forest-fire effects on carbon dioxide and energy fluxes. Agric. Forest Meteorol., 96, 199-208.

Aubinet M., Moureaux C., Bodson B., Dufranne D., Heinesch B., Suleau M., Vancutsem F., and Vilret A., 2009. Carbon sequestration by a crop over a 4-year sugar beet/winter wheat/seed potato/winter wheat rotation cycle. Agric. Forest Meteorol., 149, 407-418.

Baggs E.M., Smales C.L., and Bateman E.J., 2010. Changing $\mathrm{pH}$ shifts the microbial source as well as the magnitude of $\mathrm{N}_{2} \mathrm{O}$ emission from soil. Biology Fertil. Soils, 46, 793-805.

Baker J.M., Ochsner T.E., Venterea R.T., and Griffis T.J., 2007. Tillage and soil carbon sequestration- What do we really know? Agric. Ecosys. Environ., 118, 1-5.

Baldocchi D., Falge E., Lianhong G., Olson R., Hollinger D., Running S., Anthoni P., Bernhofer C., Davis K., Evans R., Fuentes J., Goldstein A., Katul G., Law B., Lee X., Mahli Y., Meyers T., Munger W., Oechel W., Paw K., Pilegaard K., Schmid H., Valentini R., Verma S., Vesala T., Wilson K., and Wofsy S., 2001. FLUXNET: a new tool to study the temporal and spatial variability of ecosystemscale carbon dioxide, water vapour and energy flux densities. Bull. Am. Meteorolog. Society, 82, 2415-2424.

Beer C., Reichstein M., Tomelleri E., Ciais P., Jung M., Carvalhais N., Rodenbeck C., Altaf Arain M., Baldocchi D., Bonan G.B., Bondeau A., Cescatti A., Lasslop G., Lindroth A., Lomas M., Luyssaert S., Margolis H., Oleson K.W., Roupsard O., Veenendaal E., Viovy N., Williams C., Woodward F.I., and Papale D., 2012. Terrestrial Gross Carbon Dioxide Uptake: Global Distribution and Covariation with Climate. Science, 329, 834-838.

Brus D.J., Spätjens L.E.E.M., de Gruijter J.J., 1999. A sampling scheme for estimating the mean extractable phosphorus concentration of fields for environmental regulation. Geoderma, 89, 129-148.

Butterbach-Bahl K., Baggs E.M., Dannenmann M., Kiese R., and Zechmeister-Boltenstem S., 2013. Nitrous oxide emissions from soils: how well do we understand the processes and their controls? Philosophical Transactions of the Royal Society B, 368: 20130122.

Ceschia E., Beziat P., Dejou, J.F., Aubinet M., Bernhofer C., Bodson B., Buchmann N., Carrara A., Cellier P., Di Tommasi P., Elbers J.A., Eugster W., Grunwald T., Jacobs C.M.J., Jans W.W.P., Jones M., Kutsch W., Lanigan G., Magliulo E., Marloie O., Moors E.J., Moureaux C., Olioso A., Osborne B., Sanz M.J., Saunders M., Smith P., Soegaard H., and Wattenbach M., 2010. Management effects on net ecosystem carbon and GHG budgets at European crop sites. Agriculture Ecosystems and Environment, 139, 363-383.

Chahouki M.A.Z., 2012. Classification and ordination methods as a tool for analysing plant communities. In: Multivariate 
analysis in Management, Engineering and the Sciences (Eds L. de Freitas, A. de Freitas). InTech, London, United Kingdom, pp. 221-254. http://dx.doi.org/10.5772/54101

Chamizo S., Serrano-Ortiz P., Lopez-Ballesteros A., SanchezCanete E.P., Vicente-Vicente J.L., and Kowalski A.S., 2017. Net ecosystem $\mathrm{CO}_{2}$ exchange in an irrigated olive orchard of SE Spain: Influence of weed cover. Agriculture, Ecosystems and Environment, 239, 51-64.

Ciais P., Reichstein M., Viovy N., Granier A., Ogee J., Allard V., Aubinet M., Buchman N., Bernhofer C., Carrara A., Chevallier F., De Noblet N., Friend A.D., Friedlingstein P., Grunwald T., Heinesch B., Keronen P., Knohl A., Krinner G., Loustau D., Manca G., Matteucci G., Miglietta F., Ourcival J.M., Papale D., Pilegaard K., Rambal S., Seufert G., Soussana J.F., Sanz M.J., Schulze E-D., Vesala T., and Valentini R., 2005. Europe-wide reduction in primary productivity caused by the heat and drought in 2003. Nature, 437, 529-533.

Ciais P., Wattenbach M., Vuichard N., Smith P., Piao S.L., Don A., Luyssaert S., Janssens I.A., Bondeau A., Dechow R., Leip A., Smith P.C., Beer C., van der Werf G.R., Gervois S., Van Oost K., Tomelleri E., Freibauer A., and Schulze E-D., 2010. The European carbon balance. Part 2: croplands. Global Change Biology, 16, 1409-1428.

Dahal D., Lui S., and Oeding J., 2014. The Carbon Cycle and Hurricanes in the United States between 1900 and 2011. Scientific Reports 4, 5197; DOI:10.1038/srep05197.

Davis P., Clifton Brown J., Saunders M., Lanigan G., Wright E., Fortune T., Burke J., Connolly J., Jones M.B., and Osborne B., 2010. Assessing the effects of agricultural management practices on carbon fluxes: Spatial variation and the need for replicated estimates of Net Ecosystem Exchange. Agric. Forest Meteorol., 150, 564-574.

de Araujo A.C., Dolman A.J., Waterloo, M.J., Gash J.H.C., Kruijt B., Zanchi F.B., de Lange J.M.E., Stoevelaar R., Manzi A.O., Nobre A.D., Lootens R.N., and Backer J., 2010. The spatial variability of $\mathrm{CO}_{2}$ storage and the interpretation of eddy covariance fluxes in central Amazonia. Agric. Forest Meteorol., 150, 226-237.

Dolman A., Valentini R., and Freibauer A., 2008. Observing the continental-scale greenhouse gas balance. In: The Continental-Scale Greenhouse Gas Balance Of Europe (Eds A. Dolman, R. Valentini, A. Freibauer). SpringerVerlag, Berlin.

Eugster W., Moffat A., Ceschia E., Aubinet M., Ammann C., Osborne B., Davis P., Smith P., Jacobs C., Moors E., Le-Dantec V., Beziat P., Saunders M., Jans W., Grunwald T., Rebmann C., Kutsch W., Czerny R., Janous D., Moureaux C., Dufranne L., Carrara A., Magliula V., Di-Tommasi P., Olesen J., Schelde K., Olioso A., Bernhofer C., Cellier P., Larmanou E., Loubert B., Wattenbach M., Marloie O., Sanz M-J., Sogaard H., and Buchmann, N., 2010. Management effects on European cropland respiration. Agric. Ecosys. Environ., 139, 346-362.

Fallon P. and Betts R., 2010. Climate impacts on European agriculture and water management in the context of adaptation and mitigation-The importance of an integrated approach. Sci. Total Environ., 408, 5667-5687.

Frank D., Reichstein M., Bahn M., Thonicke K., Frank D., Mahecha M.D., Smith P., Van Der Velde M., Vicca S.,
Babst F., Beer C., Buchmann N., Canadell J.G., Ciais P., Cramer W., Ibrom A., Miglietta F., Poulter B., Rammig A., Seneviratne S.I., Walz A., Wattenbach M., Zavala M.A., and Zscheischler J., 2015. Effects of climate extremes on the terrestrial carbon cycle: concepts, processes and potential future impacts. Global Change Biol., 21, 2861-2880.

Fuß R., Ruth B., Schilling R., Scherb H., and Munch JC., 2011. Pulse emissions of $\mathrm{N}_{2} \mathrm{O}$ and $\mathrm{CO}_{2}$ from an arable field depending on fertilisation and tillage practice. Agric. Ecosys. Environ., 144, 61-68.

Gielen B., Neirynck J., Luyssaert S., and Janssens I.A., 2011. The importance of dissolved organic carbon fluxes for the carbon balance of a temperate Scots pine forest. Agric. Forest Meteorol., 151, 270-278.

Gielen B., Op de Beeck M., and Papale D., 2017a. ICOS ecosystem instructions for site characterisation measurements in forests (Version 20170831). ICOS Ecosystem Thematic Centre. doi.org/10.18160/ymvv-af8m

Gielen B., Op de Beeck M., and Papale D., 2017b. ICOS ecosystem instructions for ancillary vegetation measurements in forests. (Version 20180131). ICOS Ecosystem Thematic Centre. doi.org/10.18160/4ajs-z4r9

Göckede M., Rebmann C., and Foken T., 2004. A combination of quality assessment tools for eddy covariance measurements with footprint modelling for the characterisation of complex sites. Agric. Forest Meteorol., 127, 175-188.

Hawkins E.D., Fricker T.E., Challinor A.J., Ferro C.A.T., Ho C.K., and Osborne T.M., 2013. Increasing influence of heat stress on French maize yields from the 1960s to the 2030s. Global Change Biology, 19, 937-947.

Hicke J.A., Allen C.D., Desai A.R., Dietze M.C., Hall R.J. Hogg E.H., Kashian D.M., Moore D., Raffa K.F., Sturrock R., and Vogelmann J., 2012. Effects of biotic disturbances on forest carbon cycling in the United States and Canada. Global Change Biology, 18, 7-34.

Holling C.S., 1973. Resilience and stability of ecological systems. Annual Review of Ecology and Systematics, 4, 1-23.

Hou L., Liu Y., Wang M., Wang H., and Mao P., 2016. Grazing effects on ecosystem $\mathrm{CO}_{2}$ fluxes differ among temperate steppe types in Eurasia. Scientific Reports, 6, 1-8.

Hörtnagl L. and Wohlfahrt G., 2014. Methane and nitrous oxide exchange over a managed hay meadow. Biogeosciences, 11, 7219-7236.

Hussain M.Z., Grunwald T., Tenhunen J.D., Li Y.L., Mirazae H., Bernhofer C., Otieno D., Dinh N.Q., Schmidt M., Wartinger M., and Owen K., 2011. Summer drought influence on $\mathrm{CO}_{2}$ and water fluxes of extensively managed grassland in Germany. Agric. Ecosys. Environ., 141, 67-76.

Hyde B.P., Hawkins M.J., Fanning A.F., Noonan D., Ryan M., Toole P.O., and Carton O.T., 2006. Nitrous oxide emissions from a fertilised and grazed grassland in the South East of Ireland. Nutrient Cycling in Agroecosystems, 75, 187-200.

IPCC, 2013. Good practice guidelines for land use, land-use change and forestry. (Eds J. Penman, M. Gytarsky, T. Hiraishi, et al.).

Jassal R.S., Blac A.T., Cai T., Ethier G., Pepin S., Brummer C., Nesic Z., Spittlehouse D.L., and Trofymow J.A., 2010. 
Impact of nitrogen fertilisation on carbon and water balances in a chronosequence of three Douglas-fir stands in the Pacific Northwest. Agric. Forest Meteorol., 150, 208-218.

Jimoh M.A., Kaehler S., and Botha C.E.L. 2013. Increased feeding damage under elevated $\mathrm{CO}_{2}$ : The case of the Russian wheat aphid. South African J. Botany, 84, 30-37.

Kindler R., Siemens J., Kaiser K., Walmsley D.C., Bernhofer C., Buchmann N., Cellier P., Eugster W., Gleixner G., Grunwald T., Heim A., Ibrom A., Jones S.K., Jone M., Klumpp K., Kutsch W., Larsen K.S., Lehuger S., Loubet B., McKenzie R., Moors E., Osborne B., Pilegaard K., Rebmann C., Saunders M., Schmidt M.W.I., Soussana J-F., Sutton M.A., Tefs C., Vowinckels B., Zeeman M.J., and Kaupenjohann M., 2011. Dissolved carbon leaching from soil is a crucial component of the net ecosystem carbon balance. Global Change Biology, 17, 1167-1185.

Kljun N., Calanca P., Rotach M.W., and Schmid H.P., 2015. A simple two-dimensional parameterisation for flux footprint prediction (FFP). Geoscientific Model Development, 8, 3695-3713.

Knohl A., Kolle O., Minayeva T., Milyukova I.A.M., Vygodskaya N.N., Foken T., and Schulze E-D., 2002. Carbon dioxide exchange of a Russian boreal forest after disturbance by wind throw. Global Change Biology, 8 , 231-246.

Kurz W.A., Dymond C.C., Stinson G., Rampley G.J., Neilson E.T., Carroll A.L., Ebata T., and Safranyik L., 2008. Mountain pine beetle and forest carbon feedback to climate change. Nature, 452, 987-990.

Kutsch W.L., Aubinet M., Buchmann N., Smith P., Osborne B., Eugster W., Wattenbach M., Schrumpf M., Schulze E.D., Temelleri E., Ceschia E., Bernhofer C., Béziat P., Carrara A., Di Tommasi P., Gruenwald T., Jones M., Magliulo V., Márloie O., Moureaux C., Olioso A., Sanz M.J., Saunders M., Sögaard H., and Ziegler W., 2010. The net biome production of full crop rotations in Europe. Agriculture, Ecosys. Environ., 139, 3, 336-345.

Lal R., 2002. Soil carbon dynamics in cropland and rangeland. Environmental Pollution, 116, 353-362.

Lal R., 2004. Agricultural activities and the global carbon cycle. Nutrient Cycling in Agroecosystems, 70, 103-116.

Lin H., Chen Y., Song Q., Fua P., Cleverly J., Magliulo V., Law B.E., Gough C.M., Hörtnagl L., Di Gennaro F., Matteucci G., Montagnani L., Duce P., Shao C., Kato T., Bonal D., Paul-Limoges E., Beringer J, Grace J., and Fan Z., 2017. Quantifying deforestation and forest degradation with thermal response, Science of the Total Environment, 607-608, 1286-1292.

Lindauer M., Schmid H.P., Grote R., Mauder M., Steinbrecher R., and Wolpert B., 2014. Net ecosystem exchange over a non-cleared wind-throw disturbed upland spruce forestMeasurements and simulations. Agric. Forest Meteorol., 197, 219-234.

Marañón-Jiménez S., Castro J., Kowalski A.S., Serrano-Ortiz P., Reverter B.R., Sánchez-Cañete E.P., and Zamora R., 2011. Post-fire soil respiration in relation to burnt wood management in a Mediterranean mountain ecosystem. Forest Ecol. Manag., 261, 1436-1447.

Merbold L., Eugster W., Stiegler J., Zahniser M., Nelson D., and Buchmann N., 2014. Greenhouse gas budget $\left(\mathrm{CO}_{2}\right.$, $\mathrm{CH}_{4}$ and $\mathrm{N}_{2} \mathrm{O}$ ) of intensively managed grassland following restoration. Global Change Biology, 20, 1913-1928.

Montagnani L., Zanotelli D., Tagliavini M., and Tomelleri E., 2017. Time scale effects on the environmental control of carbon and water fluxes of an apple orchard. Ecology Evolution, DOI: 10.1002/ece3.3633

Moore B.A. and Allard G., 2011. Abiotic disturbances and their influence on forest health. A review. Working paper FBS/35E FAO, Rome, Italy.

Neftel A., Fischer C., and Flechard C.H., 2006. Measurements of greenhouse gas fluxes from agriculture. International Congress Series, 1293, 3-12.

Niu S., Wu M., Han Y., Xia J., Zhang Z., Yang H., and Wan S., 2010. Nitrogen effects on net ecosystem carbon exchange in a temperate steppe. Global Change Biology, 16, 144-155.

Op de Beeck M., Gielen B., and Papale D., 2017a. ICOS ecosystem instructions for site characterisation measurements in mires (Version 20180209). ICOS Ecosystem Thematic Centre/ https://doi.org/10.18160/8bkh-gx2x.

Op de Beeck M., and Papale D., 2017b. ICOS Ecosystem Instructions for Site Characterisation Measurements in Grasslands (Version 20170517). ICOS Ecosystem Thematic Centre/https://doi.org/10.18160/xqfz-038k

Osborne B., Saunders M., Walmsley D., Jones M., and Smith P., 2010. Key questions and uncertainties associated with the assessment of the cropland greenhouse gas balance. Agric. Ecosys. Environ., 139, 293-301.

Papale D., Canfora E., and Polidori D., 2017. ICOS Ecosystem Instructions for Use the ICOS BADM (Version 20171013). ICOS Ecosystem Thematic Centre. https:/doi. org/10.18160/6m8s-fy $7 \mathrm{~m}$.

Pellis G. and Papale D., 2017. ICOS Ecosystem instructions for plant species reporting (Version 20170129). ICOS Ecosystem Thematic Centre. https://doi.org/10.18160/ as $0 \mathrm{v}-\mathrm{x} 7 \mathrm{fc}$.

Petersen S.O., Mutegi J.K., Hansen E.M., and Munkholm L.J. 2011. Tillage effects on $\mathrm{N}_{2} \mathrm{O}$ emissions as influenced by a winter cover crop. Soil Biology and Biochemistry, 43, 1509-1517.

Pinares-Patino C.S., D'Hour P., Jouany J.P., and Martin C., 2007. Effects of stocking rate on methane and carbon dioxide emissions from grazing cattle. Agric. Ecosys. Environ., 121, 30-46.

Pirk N., Sievers J., Mertes J., Parmentier F-J.W., Mastepanov M., and Christensen T.R., 2017. Spatial variability of $\mathrm{CO}_{2}$ uptake in polygonal tundra: assessing low-frequency disturbances in eddy covariance flux estimates. Biogeosciences, 14, 3157-3169.

Powers E.M., Marshall J.D., Zhang J., and Wei L., 2013. Postfire management regimes affect carbon sequestration and storage in a Sierra Nevada mixed conifer forest. Forest Ecology and Management, 297, 268-277.

Prescher A-K., Grunwald T., and Bernhofer C., 2010. Land use regulates carbon budgets in eastern Germany: From NEE to NBP. Agric. Forest Meteorol., 150, 1016-1025.

Reichstein M., Bahn M., Ciais P., Frank D., Mahecha M.D., Seneviratne S.I., Zscheischler J., Beer C., Buchmann N., Frank D.C., Papale D., Ramming A., Smith P., Thonicke 
K., van der Velde M., Vicca S., Walz A., and Wattenbach M., 2013. Climate extremes and the carbon cycle. Nature, 500, 287-295.

Reicosky D.C., Dugas W.A., and Torbert H.A., 1997. Tillageinduces soil carbon dioxide loss from different cropping systems. Soil Till. Res., 41, 105-118.

Richardson A.D., Hollinger D.Y., Aber J.D., Ollinger S.V., and Braswell B.H., 2007. Environmental variation is directly responsible for short- but not long-term variation in forestatmosphere carbon exchange. Global Change Biology, 13, 788-803.

Ruysschaert G., Poesen J., Verstraeten G., and Govers G., 2005. Interannual variation of soil losses due to sugar beet harvesting in West Europe. Agric. Ecosys. Environ., 107, 317-329.

Ryals R. and Silver W., 2013. Effects of organic matter amendments of net primary productivity and greenhouse gas emissions in annual grasslands. Ecological Applications, 23, 46-59.

Saunders M., Tobin B., Sweeney C., Gioria M., Benanti G., Cacciotti E., and Osborne B.A., 2014. Impacts of exceptional and extreme inter-annual climatic events on the net ecosystem exchange of a Sitka spruce forest. Agric. Forest Meteorol., 184, 147-157.

Schulze E-D., Ciais P., Luyssaert S., Schrumpf M., Janssens I., Thiruchittampalam B., Theloke J., Saurat M., Bringezu S., Lelieveld J., Lohila A., Rebmann C., Jung M., Bastviken D., Abril G., Grass G., Leip A., Freibauer A., Kutsch W., Don A., Nieschulze J., Borner A., Gash J., and Dolman A., 2010. The European carbon balance. Part 4: integration of carbon and other trace-gas fluxes. Global Change Biology, 16, 1451-1469.

Serrano-Ortiz P., Marañón-Jiménez S., Reverter B.R., Sánchez-Cañete E.P., Castro J., Zamora R., and Kowalski A.S., 2011. Post-fire salvage logging reduces carbon sequestration in Mediterranean coniferous forest. Forest Ecol. Manag., 262, 2287-2296.

Sjögersten S., van der Wal R., Loonen M.J.J.E., and Woodin S.J., 2011. Recovery of ecosystem carbon fluxes and storage from herbivory. Biogeochemistry, 106, 357-370.

Skiba U. and Smith K.A., 1999. The control of nitrous oxide emissions from agricultural and natural soils. Chemosphere - Global Change Science, 2, 379-386.

Smith P., Lanigan G., Kutsch W.L., Buchmann N., Eugster W., Aubinet M., Ceschia E., Beziat P., Yeluripati J.B., Osborne B., Moors E.J., Brut A., Wattenbach M., Saunders M., and Jones M., 2010. Measurements necessary for assessing the net ecosystem carbon budget of croplands. Agric. Ecosys. Environ., 139, 302-315.

Snyder C.S., Bruulsema T.W., Jensen T.L., and Fixen P.E., 2009. Review of greenhouse gas emissions from crop production systems and fertiliser management effects. Agric. Ecosys. Environ., 133, 247-266.

Stoy P.C., Mauder M., Foken T., Marcolla B., Boegh E., Ibrom A., AltafArain M., Arnet A., Aurela M., Bernhofer C., Cescatti A., Dellwik E., Duce P., Gianelle D., van Gorsel E, Kiely G., Knohl A., Margolis H., McCaughey H., Merbold L., Montagnani L., Papale D., Reichstein M., Saunders M., Serrano-Ortiz P., Sottocornola M., Spano D., Vaccari F., and Varlagin A., 2013. A data-driven analy- sis of energy balance closure across FLUXNET sites: The role of landscape heterogeneity. Agricultural and Forest Meteorology, 171-172, 137-152.

Stoyan H., De-Polli H., Bohm S., Robertson G.P., and Paul E.A., 2000. Spatial heterogeneity of soil respiration and related properties at the plant scale. Plant Soil, 222, 203-214.

Straw N.A., Fielding N.J., Green G., and Price J., 2002. The impact of green spruce aphid, Elatobium abietinum (Walker), on the growth of young Sitka spruce in Halfren forest, Wales: delayed effects on needle size limit wood production. Forest Ecol. Manag., 157, 267-283.

Thürig E., Palosuo T., Bucher J., and Kaufmann E., 2005. The impact of windthrow on carbon sequestration in Switzerland: a model-based assessment. Forest Ecol. Manag., 210, 337-350.

Ulanov N.G., 2000. The effects of windthrow on forests at different spatial scales: a review. Forest Ecol. Manag., 135, 155-167.

Ventera R.T., Burger M., and Spokas KA., 2005. Nitrogen oxide and methane emissions under varying tillage and fertiliser management. J. Environ. Quality, 34, 1467-1477.

Verma S.B., Dobermann A., Cassman K.G., Walters D.T., Knops J.M., Arkebauer T.J., Suyker A.E., Burba G.G., Amos B., Yang H., Ginting D., Hubbard K.G., Gitelson A.A., and Walter-Shea E.A., 2005. Annual carbon dioxide exchange in irrigated and rainfed maize-based agroecosystems. Agric. Forest Meteorol., 131, 77-96.

Walvoort D.J., Brus J.J., and de Gruijter J.J., 2010. An R package for spatial coverage sampling and random sampling from compact geographical strata by k-means. Computers and Geosciences, 36, 1261-1267.

Willems A., Augustenborg C., Hepp S., Lanigan G., Hochstrasser T., Kammann C., and Muller C., 2011. Carbon dioxide emissions from spring ploughing of grassland in Ireland. Agric. Ecosys. Environ., 144, 347-351.

Wingate L., Ogée J., Cremonese E., Filippa G., Mizunuma T., Migliavacca M., Moisy C., Wilkinson M., Moureaux C., Wohlfahrt G., Hammerle A., Gimeno C., Porcar-Castell A., Galvagno M., Nakaji T., Morison J., Kolle O., Knohl A., Kutsch W., Kolari P., Nikinmaa E., Ibrom A., Gielen B., Eugster W., Balzarolo M., Papale D., Klumpp K., Kostner B., Grunwald T., Joffre R., Ourcival J-M., Hellstrom M., Charles G., Longdoz B., Genty B., Levula J., Heinesch B., Sprintsin M., Yakir D., Manise T., Guyon D., Ahrends H., Plaza-Aguilar A., and Grace J., 2015. Observing canopy development and physiology using the European phenology camera network at flux sites. Biogeosciences, doi:10.5194/bg-12-5995-2015

Zanotelli D., Montagnani L., Manca G., and Tagliavini M., 2013. Net primary productivity, allocation pattern and carbon use efficiency in an apple orchard assessed by integrating eddy-covariance, biometric and continuous soil chamber measurements. Biogeosciences, 10, 3089-3108. 